\author{
Robert Bubczyk (D) \\ Uniwersytet Marii-Curie Skłodowskiej, Lublin
}

\title{
FAMILIA HERLECHINI - MOTYW CZARNYCH JEŹDŹCÓW W KULTURZE ŚREDNIOWIECZNEGO ZACHODU (XI-XII W.), JEGO NARODZINY, ZNACZENIE SYMBOLICZNE I FUNKCJE IDEOLOGICZNE
}

\author{
Abstract \\ FAMILIA HERLECHINI - THE MOTIF OF BLACK RIDERS \\ IN THE WESTERN MEDIAEVAL CULTURE ( $11^{\mathrm{TH}}-12^{\mathrm{TH}}$ CENTURIES): \\ ITS BIRTH, SYBOLISM AND IDEOLOGICAL FUNCTIONS
}

The aim of the article is the historical and socio-cultural analysis of the phenomenon of the motif of black riders which functioned in the Middle Ages. In particular, the author tries to determine the symbolic and ideological role it fulfilled in those days. This problem has not been fully researched and described and many of its aspects still await description and analysis. Research on the topic is practically absent in Polish mediaeval historiography, with one exception of a study by Leszek Słupecki. The present article analyses these issues against a broad cultural background. The analysis of the phenomenon of the black riders leads the author to a conclusion that in high Middle Ages it played very important cultural and social functions and was a useful tool of describing the reality of those times.

Keywords: $11^{\text {th }}$ and $12^{\text {th }}$-century writing, the doctrine of purgatory, motif of black horse riders, familia Herlechini, Orderic Vitalis, the Anglo-Saxon Chronicle, Walter Map

Słowa kluczowe: pisarstwo XI i XII w., doktryna czyśćca, motyw czarnych jeźdźców, familia Herlechini, Orderic Vitalis, Kronika anglosaska, Walter Map

Motyw czarnych jeźdźców, który rozwinął się w kulturze europejskiego średniowiecza, należy do grupy starych wątków, sięgających prawdopodobnie początkami epoki starożytności. Mowa tu o literackich wyobrażeniach hordy postaci demonicznych, najczęściej 
wyposażonych w atrybuty wojowników bądź średniowiecznych rycerzy (zbroje, broń), które były częścią świata umarlych. Pojawiały się na wielkich, czarnych rumakach w różnych zakątkach Europy, siejąc niepokój i budząc grozę pośród żywych mieszkańców nawiedzanych przez siebie zakątków.

W epoce średniowiecza pierwsze pisane wzmianki o owych diabolicznych osobach odnoszą się do XI stulecia. Żyjący na przełomie XI i XII w. anglonormandzki mnich benedyktyński, Orderic Vitalis (1075-ok. 1142), podjął najstarszą znaną historykom szczegółową próbę opisania tej osobliwości. Późniejsze dekady przynoszą następne świadectwa skupienia się autorów na interesującym nas wątku i ukazują jego przemiany. Z czasem temat czarnych jeźdźców umacnia swoją obecność w kulturze europejskiej i przyjmuje formę swego rodzaju toposu, który zachowuje żywotność, choć ulega pewnym modyfikacjom, aż do lat współczesnych. Odnajdziemy go w produktach kultury popularnej, takich jak zekranizowana przez Petera Jacksona (2001) powieść autorstwa Johna Ronalda Reuela Tolkiena pt. Wtadca pierścieni (1954-1955), gdzie czarni jeźdźcy pojawiają się pod postacią Nazgûli - upiorów pierścienia ${ }^{1}$. Ich motyw, zapewne pod wpływem dzieła Tolkiena, występuje w muzyce popularnej II poł. XX i pocz. XXI w., w piosenkach takich zespołów jak Led Zeppelin (Battle of Evermore, 1971), Sabaton (Shadows, 2002) czy Artrosis (Nazgul, 2006), polskiej grupy grającej gotycki metal. Czarni jeźdźcy stają się też bohaterami gier komputerowych, do których należą między innymi Wtadca pierścieni. Bitwa o Śródziemie - król Nazguli (wyd. EA Games, 2007), Śródziemie (wyd. Iron Crown Enterprises), Śródziemie. Cień Mordoru (wyd. Monolith Productions, 2014).

Celem niniejszego artykułu jest analiza trzech fabuł powstałych w okresie od końca XI w. i w XII stuleciu, które są najstarszymi zabytkami pisanymi, zawierającymi w pełni rozwinięty motyw czarnych jeźdźców. Uwzględnimy przy tym społeczno-kulturowe konteksty, w jakich doszło do ich powstania. Dokładne przyjrzenie się owym kontekstom pozwoli na zaproponowanie odpowiedzi na pytanie dotyczące funkcji, jakie pełniły dyskutowane poniżej wyobrażenia w średniowiecznym pisarstwie i szerzej - w kulturze pełnego średniowiecza.

Podejmowany tu temat nie jest obcy współczesnej nauce - w światowej mediewistyce od lat trwają dyskusje, w których badacze kultury tego okresu, głównie brytyjscy, francuscy, niemieccy, włoscy i amerykańscy, próbują określić przyczyny zainteresowania średniowiecznych autorów przybliżanym tu motywem. Z kolei polscy mediewiści, również ci zajmujący się dziejami powszechnymi, w zasadzie zagadnienie to pomijają milczeniem, jeśli nie liczyć poznawczo interesujących rozważań Leszka Słupeckiego, choć odnoszących się tylko do jednego aspektu tego złożonego problemu badawczego ${ }^{2}$. Trzeba na wstę-

1 J.R.R. Tolkien, The Lord of the Rings, London 1954-1955. Brytyjski autor, będąc wykładowcą literatury średniowiecznej na uniwersytetach w Leeds i Oxfordzie, doskonale znał spuściznę pisarską omawianej epoki, w tym dzieła Orderica Vitalisa i Waltera Mapa, zob.: M. White, Tolkien. Biografia, thum. K. Majchrzak, M. Majchrzak, Poznań 2004, s. 69-76.

2 L. Stupecki, Wojownicy i wilkotaki, Warszawa 1994, s. 98-115, szczególnie zaś s. 109-112. Autor 
pie podkreślić, że wątek czarnych jeźdźców jest ważny choćby z tego powodu, że należał $\mathrm{w}$ średniowieczu do znacznie szerszego i wieloaspektowego zagadnienia wzajemnych relacji pomiędzy światem żywych i umarłych, które wpisuje się między innymi w rozległe konteksty teologicznego rozumienia zbawienia, odkupienia i potępienia ${ }^{3}$. W tym artykule zbadamy wycinek tego zagadnienia, zajmując się jedynie odnalezieniem i zdefiniowaniem powodów - biorąc pod uwagę kluczowe argumenty w toczącej się dyskusji na ten temat i dodając własne wnioski - dla których należący (przynajmniej częściowo) do świata zmarłych czarni jeźdźcy zaczęli pobudzać średniowieczną wyobraźnię za sprawą trzech fabuł, o których poniżej.

Zanim dokonamy analizy każdej z nich, skupiając się na szczegółowym opisie tytułowego orszaku czarnych rycerzy, których Orderic Vitalis jako pierwszy nazwał „familia Herlechini" (a więc oddział, orszak, towarzysze Herlekina), wspomnijmy o podejmowanych przez kolejne pokolenia badaczy próbach wyjaśnienia etymologii tego niezwykłego imienia. W różnych wariantach przyjmuje ono formy Hellequin, Herlequin i Helething. Naukowe interpretacje w tym względzie zebrał i przedstawił Jean-Claude Schmitt, który twierdzi, że imię ,jest pochodzenia germańskiego i wiąże się z wojskiem (Heer) i ze zgromadzeniem wolnych ludzi (thing), tych jedynie, którzy noszą bron'”‘ Jak podaje Schmitt w dalszej części wywodu, takie nawiązania do wojska zmarłych mają bardzo stary początek - można je już odnaleźć w Germanii Tacyta, zaś we wczesnym średniowieczu między innymi u św. Augustyna w jego Państwie Bożym, a także w Historii Longobardów Pawła Diakona, zaś w okolicach roku 1000 - w Historiach pióra mnicha z opactwa Saint-Bénigne w pobliżu Dijon, Raula Glaubera. We wszystkich tych przekazach mowa jest o bliżej nieokreślonym wojsku zmarłych, które czasem przyjmuje fizyczną postać, zaś niekiedy słychać jedynie jego odgłosy, pojawiającym się w momentach zwrotnych dla danej społeczności, w sytuacjach krytycznych, zapowiadających nadejście śmierci lub wojny. Są to jednak wzmianki bardzo zdawkowe, pozbawione jakichkolwiek szczegółów w opisie owych zbrojnych jeźdźców5. Dopiero, jak wspomniano powyżej, na przełomie XI i XII w. interesujący nas motyw zostaje rozbudowany i zyskuje pierwszoplanowe miejsce w kilku fabułach - najpierw w Normandii, skąd nieco później trafia na Wyspy Brytyjskie - do Anglii.

przytacza m.in. fragment kroniki autorstwa Orderica Vitalisa, Historia Ecclesiastica, w którym dopatruje się nawiązania do starego, germańskiego mitu o dzikim wojsku (das wutende Heer), obecnego w pogańskich wierzeniach ludów średniowiecznej i wczesnonowożytnej Europy.

3 Spośród najnowszych prac na ten temat należy wymienić: R. B a r t le t t, The Natural and the Supernatural in the Middle Ages, Cambridge 2006; C. Watkins, History and the Supernatural in Medieval England, Cambridge 2007; A.J. Hingst, The Written World. Past and Place in the Work of Orderic Vitalis, Notre Dame 2009.

4 J.-C. Schmitt, Duchy. Żywi i umarli w spoteczeństwie średniowiecznym, tłum. A.W. L a b u d a, GdańskWarszawa 2002, s. 105. Por. The Ecclesiastical History of Orderic Vitalis, vol. 4, ks. VII i VIII, ed. M. Chibnall, Oxford 1983, s. 242, przyp. 3.

5 J.-C.Schmitt,op. cit., s. 105-112. 
Orderic Vitalis był pierwszym autorem, który w celu przedstawienia tego wątku wyodrębnił w VIII księdze swojej Historia Ecclesiastica osobny rozdział. Żyjący na przełomie XI i XII w. kronikarz pochodził z Anglii, ale dorosłe życie spędził w klasztorze w Normandii. Przyszedł na świat w roku 1075 w miejscowości Atcham w hrabstwie Shropshire, jako najstarszy syn francuskiego księdza i rodowitej Angielki. Zgodnie z wolą rodziców Orderic został oddany na wychowanie i naukę do opactwa w Shrewsbury, a następnie, w wieku 11 lat, rozpoczął zakonną posługę w normandzkim opactwie Saint-Evroul, gdzie spędził resztę życia jako pełnoprawny członek zakonnej wspólnoty. Na przełomie XI i XII stulecia benedyktyński dom zakonny Orderica cieszył się dobrą sławą wśród możnych panów feudalnych z Anglii, Francji i Włoch, którzy chętnie wybierali to miejsce jako cel swoich pobożnych donacji i wizyt. Opactwo posiadało też liczne dobra w Anglii i przeprowadzato własne fundacje w południowych Włoszech, co sprzyjało otwarciu się tej wspólnoty na świat. Orderic miał wielokrotnie okazję dowiedzieć się o ważnych sprawach europejskiego formatu i to bezpośrednio z ust osób w nie zaangażowanych. Sam kilkakrotnie odbywał podróże, między innymi do Worcester, Cambrai i do Cluny - opactwa słynnego z zapoczątkowania dzieła odnowy życia monastycznego. Uczestnictwo w benedyktyńskiej duchowości, wzorującej się na kluniackiej reformie ${ }^{6}$, musiało wywrzeć wpływ na sposób, w jaki Orderic przedstawiał interesujące nas wydarzenia w swojej Historia Ecclesiastica. Monumentalne dzieło powstawało przez kilkadziesiąt lat, od około 1110-1115 do 1142. Prawdopodobnie wkrótce po ukończeniu kroniki jej autor zmarł 7 .

Interesujący nas wątek odnajdziemy w opisie zdarzenia, które według Orderica miało miejsce w nocy 1 stycznia $1091 \mathrm{r}$. w normandzkiej diecezji Lisieux. W kronice czytamy, że w tym czasie młody ksiądz o imieniu Walchelin, uprzednio odwiedziwszy chorego parafianina, wracał o zmroku do swego domu. W pewnym momencie swojej pieszej wędrówki, wciąż znajdując się z dala od ludzkich siedzib, duchowny usłyszał narastające odgłosy, które przypominały łoskot wydawany przez nadciągającą armię. Wkrótce oczom jego ukazały się oświetlone blaskiem księżyca, wędrujące pieszo lub jadące konno upiorne postacie zmarłych, pośród których duchowny rozpoznawał swoich sąsiadów. Przemieszczający się z rumorem tłum był bardzo różnorodny, pogrupowany wedle ówczesnych podziałów społecznych i ekonomicznych ${ }^{8}$. W osobnych szpalerach mijały księdza zjawy ludzi ubogich i bogatych, mężczyzn i kobiet, świeckich i duchownych. Wszyscy jęczeli, cierpiąc

6 Na temat reformy kluniackiej i jej wpływu na średniowieczny monastycyzm m.in. we Francji, Niemczech i Anglii zob. C.H. Lawrence, Monastycyzm średniowieczny, tłum. J. Tyczyńska, Warszawa 2005, s. 88-109.

7 Marjorie Chibnall we wstępie do: The Ecclesiastical History of Orderic Vitalis, vol. 1, ks. I i II, ed. M. Chibnall, Oxford 1980; Orderic Vitalis. Life, Works and Interpretations, eds. C. Rozie r [et al.], Woodbridge 2016.

8 Na temat ideologicznego znaczenia trójdzielnego schematu społeczeństwa feudalnego zob. J. Flori, Rycerze i rycerstwo w średniowieczu, tłum. E. Trojańs k a, Poznań 2003, s. 182-186. 
z powodu, co zaznaczył Orderic, swoich popełnionych za życia zbrodni („ob facinora sua torquebantur") 9 .

Jako ostatnia grupa tej liczebnej kompanii nieżywych, czytamy w dziele Orderica, pojawiła się horda czarnych rycerzy na wielkich karych rumakach. Każdy z nich w pełnym bojowym rynsztunku, jak gdyby szykując się do bitewnej szarży, wyposażony w kruczoczarny proporzec, pędził w dal. Przyjrzawszy się im dokładnie, Walchelin rzekł do siebie, że owi rycerze to nikt inny jak zastępy Herlekina („haec sine dubio familia Herlechini est”). Nie wyjaśnił wszak, kogo rozumie pod tym imieniem, aczkolwiek stwierdził, co skrupulatnie odnotował Orderic Vitalis, że już wcześniej słyszał opowieści o nich od wielu rozmówców, ale z powodu braku dowodów nigdy nie dawał im wiary.

Zaraz potem czytamy, że krzepki i odważny ksiądz podejmuje próbę zatrzymania jednego z przejeżdżających obok czarnych wierzchowców bez jeźdźca. Duchowny śmiałek zamierza nań wskoczyć i pognać do domu, aby móc pokazać go sąsiadom na dowód swojej niecodziennej przygody. Schwytany za wędzidło rumak wyrywa się jednak i galopuje za resztą gromady. Drugi z koni, wypuszczając olbrzymie kłęby pary z nozdrzy, zatrzymuje się przed Walchelinem, ale gdy ten już ma go dosiąść, wkładając stopę w strzemię, czuje pod nią palący ogień, zaś jego serce przenika przeraźliwe zimno, wiodące od ręki, którą uchwycił siodło. W tym momencie nadjeżdża kolejna grupka upiornych rycerzy, którzy zatrzymują się i przemawiają do przerażonego księdza. Jeden z nich, przedstawiwszy się jako William z Glos, wyznaje, że za życia popełnił ciężki grzech lichwy. Zawłaszczył młyn, który wziął w zastaw od pewnego skromnego człowieka w zamian za udzielenie mu lichwiarskiej pożyczki - w praktyce niemożliwej do spłacenia. Za karę ów grzeszny rycerz już jako zjawa pokutuje, nosząc w ustach żelazną oś z rzeczonego młyna, która pali go żywym ogniem. Rycerz prosi księdza, by ten przekazał członkom jego rodziny, żonie Beatrice i synowi Rogerowi, by ci pomogli mu, oddając młyn prawowitym właścicielom. Pomimo nalegań duchowny odmawia swego pośrednictwa, twierdząc, że nigdy nie ośmieli się przekazywać komukolwiek żywemu wiadomości od przeklętych, niepogodzonych z Bogiem grzeszników („execrabilis biotanati”). Ta odpowiedź rozwściecza upiora, który chwyta kapłana za gardło w palącym uścisku i dusi go, ale oto nadjeżdża kolejny czarny rycerz. Ten zaś, wymachując nagim mieczem i krzycząc, nakazuje pozostałym, żeby zostawili w spokoju jego brata. Wojownicy odjeżdżają, a rycerz-zjawa, o imieniu Robert, zwraca się do osłupiałego z przerażenia księdza ze słowami, w których przedstawia mu dowody potwierdzające, że obydwaj byli rzeczywiście rodzonymi braćmi. Mówi też, że po swojej śmierci cierpi za popełnione za życia grzechy (tak zresztą jak pozostali rycerze z tego pochodu) straszliwe katusze. Do jego głównych przewinień należało rozlewanie ludzkiej krwi, za co teraz pokutuje. Potwornie ciężkie uzbrojenie, które musi dźwigać

9 „Multos etiam vicinorum suorum qui nuper obierant presbiter ibidem recognovit et merentes pro magnis suppliciis quibus ob facinora sua torquebantur audivit". Zob.: The Ecclesiastical History..., vol. 4, s. 238. 
pokutnik, jest rozgrzane do czerwoności, płonie wiecznym ogniem i do tego straszliwie cuchnie. Po przytroczonych do butów ostrogach nieustannie pełzają płomienie, palące stopy upiornego rycerza. Wszystko to powoduje niewyobrażalne męki, których na domiar złego penitent nie może przekazać nikomu innemu. A jednak pośród tej przerażającej, zdawałoby się rozpaczliwej, potępieńczej tułaczki pojawia się cień nadziei, którego chwyta się Robert. Okazuje się bowiem, jak skrupulatnie relacjonuje Orderic, że już lata wcześniej, w momencie kiedy Walchelin został wyniesiony do kapłańskiego stanu i odśpiewał swoją pierwszą mszę, ciężka tarcza - element pokutnego ekwipunku upiornego rycerza, wypadła z jego ręki, przynosząc mu odrobinę ulgi w cierpieniu. Przedstawiając ten fakt swemu bratu, Robert dodaje, że mocno wierzy w możliwość rychłego odkupienia swoich grzechów i miłosierdzie Stwórcy. Zna nawet prawdopodobny termin uwolnienia siebie od kary - ma się to odbyć w rok po najbliższej Niedzieli Palmowej. Błaga przy tym Walchelina, by ten pomógł mu uzyskać Boże przebaczenie poprzez modlitwę i pobożną jałmużnę. Ksiądz otrzymuje też z ust brata przestrogę: powinien poprawić swe własne życie, bowiem przemija ono nieubłaganie, a jego kapłański żywot pozostawia wiele do życzenia w kwestiach moralnych, gdyż jest splamiony wieloma występkami. Po chwili czarny rycerz, spinając karego rumaka do galopu, pospiesznie odjeżdża, aby dołączyć do grupy upiornych jeźdźców.

Kończąc ten wątek, autor całej historii, Orderic Vitalis, pisze, zapewniając czytelników o wiarygodności swojego przekazu, że opowieść usłyszał bezpośrednio z ust Walchelina, a nawet widział bliznę na jego szyi po żelaznym uścisku straszliwego rycerza. Benedyktyński mnich spisał dla potomnych wszystko, co zapamiętał, aby zachęcić dobrych do czynienia dobra, zaś złych do opamiętania się („ad aedificationem legentium scripsi ut in bonis consolidentur iusti, et a malis resipiscant perversi" ${ }^{10}$.

Niezwykłe pod każdym względem spotkanie księdza Walchelina z przedstawicielami świata umarłych stawia w interesującej nas kwestii włączenia czarnych jeźdźców w fabułę kilka niełatwych pytań. Nie podając etymologii imienia lidera owej rzeszy wojowników, nazwanej „familia Herlechini”, średniowieczny autor wydaje się odwoływać do jakiejś nieznanej nam, a być może posiadanej przez swoich czytelników wiedzy na ten temat. Niewykluczone, że Orderyk założył, że powszechnie wiadomo, o kim mowa w opowiadaniu. Zwraca uwagę, co niedawno słusznie podniosła analizująca ten wątek Amanda Hingst, ujęcie fizyczności przedstawionych zjaw, z którymi styka się bohater opowieści. Pomimo iż należą one do świata zmarłych, Walchelin doświadcza ich prawie takich, jakimi były za ziemskiego żywota. Upiorni rycerze nie są eteryczni i nie przenikają przez obiekty materialne. Co więcej, podążają tym samym traktem, którym chodzą żyjący, mają te same kształty i wydają ziemskie, dobrze słyszalne odgłosy. Walchelin próbuje dosiąść prawdziwego konia

10 Ibidem, s. 236-250. Por. dość szczegółowe streszczenie tego fragmentu dzieła Orderica Vitalisa w thumaczeniu na j. polski: J.-C. S ch mit t, op. cit., s. 100-102. 
i chwyta za jego autentyczne siodło, a gdy ręka upiornego rycerza zaciska się na jego gardle, pozostawia na nim swój widoczny odcisk w postaci blizny. W tym kontekście na uwagę zasługuje nierozerwalny do końca, nawet poprzez fakt śmierci, związek umarłych ze światem żywych, z którego niby odeszli, ale nie stracili z nim wszelkiej łączności ${ }^{11}$. Pomimo iż cierpią piekielne męki z powodu grzesznego żywota, nie trafili do piekła, jakie wówczas znało chrześcijaństwo $^{12}$, ale podążają szlakami, którymi chodzili za życia w okolicach doczesnego pomieszkiwania. Osobie żyjącej dane jest nie tylko, co poświadcza Orderic Vitalis, ujrzeć ich, ale nawet skutecznie komunikować się z nimi.

Przynajmniej od lat 80 . XX stulecia badacze tej i innych fabuł odnoszących się do kontaktów zmarłych ze światem żywych w omawianym okresie wskazują na związek przeżycia Walchelina z ewolucją chrześcijańskiej koncepcji czyśćca. Jest to problem sam w sobie bardzo rozległy i złożony, którego nie sposób, ani też nie ma potrzeby, definitywnie rozstrzygać w tym miejscu. Niemniej jednak ze względu na powiązanie z nim dyskutowanego tu wątku należy wspomnieć, że badaczem, który dokonał przełomu w trwającej dyskusji wśród mediewistów o czasie ugruntowania się doktryny czyśćca, był Jacques Le Goff. Wybitny francuski historyk kultury średniowiecza wskazał w swej książce pod sugestywnym tytułem Narodziny czyśćca schyłek XII stulecia jako czas ostatecznego formowania się kategorii chrześcijańskiego purgatorium ${ }^{13}$. Mediewista z Francji przeanalizował dziesiątki przekazów pisanych, które doprowadziły go do powyższego wniosku, jednak nie uwzględnił w swoich rozważaniach dzieła Orderica.

Można próbować odpowiedzieć na pytanie, dlaczego właśnie w podanym przez Le Goffa czasie ostatecznie kształtuje się doktryna czyśćca. Niewątpliwie okres XII stulecia w dziejach kultury europejskiej należał do wyróżniających się pod wieloma względami. Wówczas dokonały się liczne przemiany w różnych dziedzinach kultury, określane często mianem renesansu XII w., którego jedną z mierzalnych konsekwencji były pierwsze zachodnie uniwersytety ${ }^{14}$. Zarówno w tym czasie, jak i w następnym stuleciu, co podkreślił

11 A.J. Hingst, op. cit., s. 92-100. Por. recenzja tej monografii: L. A she, The Written World: Past and Place in the Work of Orderic Vitalis by Amanda Jane Hingst, „The Journal of English and Germanic Philology”, 2010, vol. 109, No. 4, s. 527-530.

12 A. Turner, Historia piekta, tłum. J. Jarn i ewicz, Gdańsk 2004.

13 J. Le Goff, Narodziny czyśćca, thum. K. Kocjan, Warszawa 1997; por. C. Watkins, History and the Supernatural in Medieval England, Cambridge 2007, s. 172, przyp. 7; J. Le Goff, Niezwykli bohaterowie $i$ cudowne budowle średniowiecza, thum. K. Marczewska, Warszawa 2011, s. 49-60. W polskiej historiografii zagadnienie narodzin koncepcji czyśćca, zgadzając się z argumentacją Le Goffa, podejmował m.in. Jacek Sokolski, zob. Henryk z Sawtry, Czyściec Świętego Patryka, tłum. i oprac. J. Sokolski, Wrocław 2014, s. 7-8. Wykaz i omówienie średniowiecznej łacińskiej literatury wizyjnej, w której można odnaleźć ewolucję poglądów na miejsce czyśćca w teologii zbawienia zob.: E. Gard in er, Medieval Visions of Heaven and Hell: A Sourcebook, New York-London 1993.

14 European Transformations: The Long Twelfth Century, eds. T. Noble, J. van Engen, Notre Dame 2012; I.P. We i, Intellectual Culture in Medieval Paris, Cambridge 2012, s. 8-86. 
ostatnio Carl Watkins, w Kościele podejmowana była próba wzmocnienia uniwersalnych, tradycyjnych wartości w religijnych wspólnotach lokalnych. Jednym z elementów tych działań stało się potęgowanie poczucia winy przy jednoczesnym umacnianiu przekonania, że środki do walki z grzechem są ograniczone. Takie poglądy Kościoła znajdowały odzwierciedlenie w licznych pracach ówczesnych duchownych intelektualistów ${ }^{15}$. Przejawy tego typu działań widoczne są w przytoczonych wyżej fragmentach dzieła Orderica Vitalisa. W fabule z wykorzystaniem orszaku potępieńców nacisk położony jest na przedstawienie kar, jakich doświadczają. Rzuca się w oczy otaczający i palący ich ogień, co przypomina bardziej kary piekielne niż męki czyśćcowe, choć z drugiej strony w symbolice chrześcijańskiej ogień pojmowany był jako oczyszczający ${ }^{16}$. Przykład czarnego rycerza, Williama z Glos, jest drastyczny, ale zarazem wyraźny i pouczający. Zgodnie z tradycyjną teologią pokutną pokazuje, że po śmierci nie ma miejsca dla oczyszczenia z grzechów; owszem można i trzeba za nie pokutować, ale wówczas, gdy jeszcze nie jest na to zbyt późno, to znaczy w czasie ziemskiego żywota. W wizji Walchelina przeważa właśnie taka interpretacja. Niekończące się cierpienie bez możliwości jakiejkolwiek odmiany jest prostą konsekwencją ziemskich przewinień. A jednak nie jest to opinia w stu procentach jednoznaczna w odniesieniu do wszystkich przedstawionych w historyjce postaci. Nowe przesłanie wprowadza tutaj pojawienie się rycerza Roberta. Pokutujący grzesznik wprost zapowiada rychłe zakończenie odbywania kary, podając nawet datę końca swych mąk. Stanie się tak za wstawiennictwem wciąż żyjącego brata, który ma możliwość wzmocnienia działania Bożego miłosierdzia poprzez modlitwy i jałmużnę w intencji zmarłego członka rodziny.

W świetle przytoczonych faktów zdaje się bardzo prawdopodobne, że w czasie, kiedy powstawała Historia Ecclesiastica, powolne klarowanie się koncepcji czyśćca, jako alternatywy dla przeważającego w ówczesnej chrześcijańskiej eschatologii dualistycznego podziatu na niebo i piekło, dobiegało końca, co znajduje potwierdzenie w historii Walchelina ${ }^{17}$. Orderic Vitalis przyjął w tej kwestii jeszcze postawę niepewną, nacechowaną wahaniem. $Z$ jednej strony głosił nieuchronność i nieodwołalność kary za grzeszne czyny, z drugiej zaś, co przedstawił w swej kronice za pomocą sceny spotkania dwóch braci - dopuszczał już perspektywę skrócenia katuszy jako kary za ciężkie przewinienia. Co istotne dla naszych rozważań, benedyktyński reformator z klasztoru w Evroul skorzystał przy konstruowaniu swej opowieści ze starego, jak wspomniano, zapewne przedchrześcijańskiego motywu upiornych jeźdźców, który - udramatyzowany zgodnie z duchem czasu (wojownicy to feudalni rycerze) i dostosowany do dydaktycznego przesłania - jak widać, doskonale

15 C. Watkins, op. cit., s. 170-180.

16 D. Forstner, Świat symboliki chrześcijańskiej, tłum. W. Za kr zew ska [et al.], Warszawa 1990, s. 73-76.

17 Z. Dan i ele wi icz, Niebo. Historia przysztości, Warszawa 2005, por. Ch. Fr u go n i, Books, Banks, Buttons and Other Inventions from the Middle Ages, New York 2003, s. 83-85. 
nadawał się jako literacki środek do wyrażenia opinii w jednej z kwestii kluczowych dla teologii zbawienia ${ }^{18}$.

Po raz kolejny wątek czarnych jeźdźców pojawia się w anonimowej kronice spisanej w języku anglosaksońskim w angielskim opactwie Peterborough w latach 1070-115419, przy okazji relacjonowania wydarzeń z lutego $1127 \mathrm{r}$. Znamienne jest, że tym razem autor dzieła sięga po omawiany przez nas motyw ponownie, choć wykorzystuje go w nieco zmienionej formie i w innym kontekście, czemu przyjrzymy się bliżej.

Pisząc o królewskim nadaniu rzeczonego opactwa Henrykowi z Poitou, krewnemu angielskiego króla Henryka I (1100-1135), podkreśla niezadowolenie hierarchów Kościoła z tej decyzji, gdyż według nich wspomniana nominacja była niekanoniczna. Na dodatek, jak czytamy w kronice, nowy opat, zadomowiwszy się w nowym miejscu, zachowywał się tam „jak trutnie w pszczelim ulu” (w tłumaczeniu na współczesny j. angielski: „as drones do in a hive"), czerpiąc jedynie korzyści z urzędowania i wywożąc za granicę wszelkie zasoby opactwa, nie przyczyniał się do jego rozwoju. Nieznany z imienia kronikarz przedstawia też, co dla nas najważniejsze, sekwencję zdarzeń, które miały miejsce zaraz po tym, jak nowy opat przybył do Peterborough.

W owym czasie - dowiaduje się czytelnik - wielu ludzi słyszało, a nawet widziało, dużą liczbę jeźdźców, których autor nazywa myśliwymi. Byli czarni, wielcy i mieli odrażający wygląd, przemieszczali się po okolicznych lasach na karych wierzchowcach i czarnych kozłach. Towarzyszyła im sfora masywnych, czarnych i wstrętnie wyglądających ogarów o wielkich ślepiach. W porze nocnej wielu mnichów słyszało dźwięki myśliwskich rogów, zaś „ludzie, którym można zaufać” (ang. trustworthy people), jak podkreślił autor, widzieli nocą gromadę 20-30 dmących w rogi postaci. Kończąc ten wątek, kronikarz dodał, że widziano i słyszano czarnych jeźdźców przez cały post aż do Wielkanocy ${ }^{20}$.

W przywołanym fragmencie grupa czarnych jeźdźców nie zostaje nazwana z imienia, choć posiadają oni kilka cech upodabniających ich do upiornych rycerzy z opowieści Orderica Vitalisa. Podobieństwo dotyczy przede wszystkim ich zewnętrznego wyglądu: są czarni, budzą grozę i dosiadają karych rumaków lub też, i tu jest nowość, czarnych kozłów. Wiele elementów tego przedstawienia wskazuje na to, że znów mamy do czynienia z postaciami demonicznymi. Świadczą o tym ich odrażające sylwetki, a także fakt, że owi jeźdźcy pojawiają się w nocy. Poza tym miejscem ich „dzikiego polowania” jest las, utożsamiany przez ludzi średniowiecza z siedliskiem demonów. „Las - pisze Stanisław

18 Według Jean-Claude’a Schmitta omawiany tu wątek pełnił jeszcze inną funkcję. Przedstawienie grupy grzesznych rycerzy i ukazanie, jakich to zbrodni się dopuścili i jakie męki musieli za to cierpieć, stanowił głos „mnicha reformatora” w walce Kościoła o treuga dei. Zob. J.-C. S ch m it t, op. cit., s. 104.

19 C. Clark, The Peterborough Chronicle, 1070-1154, Oxford 1958.

20 The Anglo-Saxon Chronicle, thum. na j. ang. i oprac. D. Whitelock, D.C. Douglas, S.I. Tucker, London 1961, s. 193-194. Na temat pierwszej wersji kroniki zob. J.-C. S ch mitt, op. cit., s. 113, przyp. 37. 
Kobielus - ucieleśniał [...] lęk, niebezpieczeństwo, ciemność, zagubienie i brak drogi oraz światła" ${ }^{\text {. }}$. Nie bez znaczenia jest przedstawienie w czarnej barwie zarówno jeźdźców, jak i dosiadanych przez nich zwierząt, a także towarzyszących im myśliwskich psów o wyłupiastych ślepiach. W symbolice chrześcijańskiej była to barwa „śmierci i królestwa zmarłych”, „wiecznej ciemności, grzechu i szatana”22. Niektórzy ze zgrai diabolicznych łowców jeździli na czarnych kozłach. W wiekach średnich były one symbolem grzeszników, a niekiedy - co podkreślili w swych pracach między innymi Gerald Messadié, Maximilian Rudwin, Donat de Chapeaurouge, a z polskich badaczy Michał Rożek i Katarzyna Zalewska-Lorkiewicz utożsamiano je wprost $\mathrm{z}$ diabłem ${ }^{23}$. Kare rumaki również cieszyły się wątpliwą estymą, zaś jeden z pierwszych ich symbolicznych opisów odnajdziemy w Apokalipsie św. Jana. Hraban Maur, uczony kronikarz czasów karolińskich, pisał o koniu takiej maści: „czarny oznacza wspólnotę fałszywych braci, którzy trzymając wagę prawdziwej wiary, ranią współbraci uczynkami ciemności”²4.

$\mathrm{Z}$ przywołanego fragmentu nie dowiemy się niczego wprost o statusie społecznym owych myśliwych, ale w pełnym średniowieczu polowanie, zwłaszcza w sposób zorganizowany, w grupie, należało do kanonu zajęć arystokracji feudalnej, przede wszystkim rycerstwa ${ }^{25}$. Prawdopodobne zatem, że drużyna upiornych jeźdźców była, w zamyśle kronikarza z Peterborough, uformowana z przedstawicieli tego stanu ${ }^{26}$. Sądząc z przedstawionych w kronice okoliczności, w których doszło do pojawienia się rzeczonych watah, jej autor wiązał w łańcuch przyczynowo-skutkowy te zdarzenia z niesłuszną, zdaniem wielu przedstawicieli Kościoła, nominacją Henryka z Poitou i jego niegodziwymi działa-

21 S. Ko bi elu s, Florarium christianum. Symbolika roślin - chrześcijańska starożytność iśredniowiecze, Kraków 2014, s. 117-118. Por. na temat lasu w tradycji celtyckiej: I. Chojn owska-Haponik, Tajemnice lasu Brocéliande. Legenda, rzeczywistość i wizja literacka, [w:] Flora i fauna w kulturze średniowiecza od XI do $X V$ wieku, red. A. Karłow sk a-Ka m zow a, Poznań 1997, s. 15-20.

22 D. Forstner, op. cit., s. 117; A.M. di Nola, Diabet, tłum. I. Kan ia, wyd. 2, Kraków 2000, s. 180, 203; por. D. de Cha pe a u roug e, Symbole chrześcijańskie, tłum. G. Raw ski, Kraków 2014, s. 168-170.

23 G. Messadié, Diabet. Historia powszechna, tłum. K. Szeżyńska-Maćkowiak, Warszawa 1998, s. 395-396; M. Rudwin, Diabet w legendzie i literaturze, tłum. J. Illg, Kraków 1999, s. 51-64; D. de Ch ape a u ro uge, op. cit., s. 119; M. Rożek, Diabet w kulturze polskiej. Szkice z dziejów motywu i postaci, Warszawa-Kraków 1993, s. 94; K. Zalewska-Lorkiewicz, Książe ciemności. O średniowiecznych wyobrażeniach szatana, Warszawa 1996, s. 79.

24 Cyt. za: S. Kobielus, Bestiarium chrześcijańskie. Zwierzęta w symbolice i interpretacji. Starożytność iśredniowiecze, Warszawa 2002, s. 144-149.

25 C. Reeves, Pleasures and Pastimes in Medieval England, Stroud 1995, s. 103-114; D. Piw ow a rczyk, Obyczaj rycerski w Polsce późnośredniowiecznej (XIV-XV wiek), Warszawa 1998, s. 148-157; A. Sa msonowicz, Eowy - praca, zabawa, obyczaj, [w:] Cztowiek i przyroda w średniowieczu i we wczesnym okresie nowożytnym, red. W. Iwańczak, K. B racha, Warszawa 2000, s. 141-152; F. Kusiak, Rycerze średniowiecznej Europy tacinskiej, Warszawa 2002, s. 274-284.

26 Oficjalny stosunek duchowieństwa do polowań był z reguły negatywny, wyjątek stanowiło polowanie na jelenia. Zob. M. Pastoureau, Średniowieczna gra symboli, thum. H. Ig a ls on-Tyg i elsk a, Warszawa 2006, s. 87-88. 
niami już jako nowego zwierzchnika opactwa Peterborough. Hordy czarnych myśliwych, którym bliżej było do piekła niż do świata żywych, mąciły spokój lokalnej wspólnoty, poświadczając swoją obecnością brak porządków prawnego i moralnego, zburzonych złą decyzją króla i pychą opata.

Na podstawie fragmentu kroniki z Peterborough zauważamy, że omawiany przez nas powyżej wątek czarnych jeźdźców po raz kolejny zajął ważne miejsce w średniowiecznej wyobraźni. Tym razem zmieniła się jego funkcja, bowiem nie wykorzystano go do dyskusji o sprawach ostatecznych. Anonimowy autor posłużył się nim do skomentowania i zobrazowania polityczno-społecznej sytuacji, w jakiej znalazła się lokalna wspólnota.

Jest wreszcie trzecia, nieco tylko późniejsza od dwóch poprzednich, odsłona wątku czarnych jeźdźców, która pokazuje zastosowanie go w jeszcze innej funkcji. W II poł. XII stulecia temat wędrujących jeźdźców powraca w dziele znanym jako De nugis curialium, które wyszło spod pióra Waltera Mapa, anglonormandzkiego klerka i zarazem dworzanina angielskiego króla Henryka II Plantageneta ${ }^{27}$. W dwóch miejscach napisanego po łacinie zbioru opowieści ich autor wspomina o jeźdźcach w słowach, którymi nawiązuje do grupy konnych wędrowców, znanych nam z historii Orderica Vitalisa. Map nazywa ich Herlethingi. Autor wyjaśnia nawet etymologię tego słowa, wyprowadzając nazwę od imienia Herla, o którym twierdzi, że był mitycznym królem Brytów. Zdaniem królewskiego klerka obecność konnej kawalkady pod wodzą tego władcy odnotowywali mieszkańcy pogranicza walijsko-angielskiego niejednokrotnie, po raz ostatni dostrzegając ją w pierwszym roku panowania króla Henryka II (czyli w roku 1154).

W jednym z rozdziałów swego dzieła Walter Map przytacza barwną historię, w której przedstawia okoliczności, w jakich miało miejsce uformowanie się grupy jeźdźców pod przywództwem Herli. Dowiadujemy się z niej, że w zamierzchłych czasach, kiedy na Wyspach Brytyjskich panował król Herla, doszło między nim a tajemniczym królem-karłem istotą nadprzyrodzoną - do zawarcia pewnej umowy. Ów zagadkowy monarcha wzrostem nie przewyższał małpy, miał brzydką, wielką głowę, długą, zwisającą na piersi rudą brodę, kopyta zamiast stóp i poruszał się na dużym koźle. Ten pokraczny przybysz zaproponował Herli układ, w następstwie którego znalazł się w gronie gości na uroczystościach weselnych Herli z nieznaną z imienia frankijską królewną. Rok później - zgodnie z umową - doszło do rewizyty: tym razem to Herla ze swym orszakiem wziął udział w weselu króla-karła. Odbywało się ono w nocnej scenerii w przedziwnym miejscu, do którego docierało się poprzez jaskinię umieszczoną wysoko w jednym z nadmorskich klifów. Po zakończeniu uroczystości weselnych Herla wyruszył ze swym dworem w drogę powrotną. W prezencie odebrał od swego gospodarza między innymi psa gończego, buldoga (,canem modicum

27 Na temat biografii i kariery Waltera Mapa zob.: R. Bubczyk, W stużbie Kościota i króla. Waltera Mapa droga do kariery w czasach panowania angielskich Plantagenetów, [w:] Historia narrat. Studia mediewistyczne ofiarowane profesorowi Jackowi Banaszkiewiczowi, red. A. Pleszczyńs ki [et al.], Lublin 2012, s. 161-175. 
sanguinarium”), którego miał trzymać w czasie konnej podróży w siodle, z zastrzeżeniem, że nie wolno zarówno jemu, jak i żadnemu z jego towarzyszy zejść z konia, dopóki najpierw nie zrobi tego pies. Wkrótce potem okazało się, jak brzemienna w skutki była owa wizyta. Trzy dni spędzone w siedzibie króla-karła odpowiadało upływowi setek lat ziemskiego czasu, zaś próba zejścia z koni na ziemię bez oglądania się na niewzruszenie siedzącego w siodle psa - na co odważyli się niektórzy towarzysze króla - kończyła się obróceniem śmiałków w proch. Tak oto, pisze Map, tułał się odtąd król Herla ze swoim orszakiem, znalazłszy się jak gdyby poza czasem. Drużyna Herli nie należała już do świata żywych i do niego powrócić nie mogła, będąc skazaną na wieczną poniewierkę w ponadczasowym zawieszeniu. Jednocześnie zaś nie dane jej było odejść do krainy umarłych. Błąkali się więc nieszczęśni wędrowcy nieustannie: gdziekolwiek pojawiali się, przerażeni ludzie krzyczeli i dęli w rogi, chwytali za broń, ale wówczas orszak znikał. Takie spotkanie miało miejsce po raz ostatni z początkiem panowania Henryka II. W okolicach Hereford, jak donieśli miejscowi Walijczycy, orszak króla Herli wskoczył do rzeki Wye i wszelki ślad po nim zaginął. W opinii Waltera Mapa stało się tak dlatego, że dotychczasowa tułaczka orszaku Herli została scedowana na dworzan angielskiego władcy, do których przynależał również i autor całej opowieści ${ }^{28}$.

Przytoczony powyżej wątek, który przynosi nam kolejne informacje o czarnych jeźdźcach, stanowi przedmiot nieustającego zainteresowania badaczy z kilku powodów. Analizując ten fragment dzieła De nugis curialium, Jean-Claude Schmitt podkreślił znaczenie opowieści o królu Herli w stworzeniu ajtiologicznego mitu królewskiego dworu, w którym Map odesłał czytelników do celtyckich początków Wielkiej Brytanii. Francuski historyk zwrócił też uwagę na zawarte w tym tekście wyraźne odniesienia do folkloru celtyckiego ${ }^{29}$. Wtórując mu, włoski badacz tego zagadnienia, Alberto Varvaro, zasugerował ponadto, że król-karzeł był postacią diaboliczną, na co wskazują jego wygląd i zachowanie. Zetknięcie się z nim króla Herli i przyjęcie od niego licznych prezentów zostało opłacone za cenę braku możliwości powrotu do świata żywych ${ }^{30}$. Monika Otter z kolei zaakcentowała kwestię „wyrwania” króla Herli i jego towarzyszy podróży z ludzkiego czasu, co zmusiło ich do niekończącego błąkania się. Owa opowieść była jej zdaniem, co jest przekonującą tezą, swoistą metaforą zawieszenia dworskich klerków, takich jak Walter Map, w przestrzeni pomiędzy statusem świeckim i duchownym, pomiędzy własnym wykształceniem a przywilejami, jakie dawał status arystokraty ${ }^{31}$.

28 Walter Map, De nugis curialium. Courtiers' Trifles, oprac. i tłum. M.R. Ja m es, R. My n o r s, Oxford 1983, s. 26-30, 370-372.

29 J.-C. Schmitt, op. cit., s. 116-117.

30 A. Varvaro, Apparizioni fantastiche. Tradizioni folcloriche e letteratura nel Medioevo, Mulino 1994, s. $132-138$.

31 M. Otter, Inventiones: Fiction and Referentiality in Twelfth-Century English Historical Writing, Chapel Hill-London 1996, s. 120, 126-127. 
Badając życiorys Waltera Mapa, który w pewnym stopniu można zrekonstruować na podstawie autobiograficznych wtrętów na temat realiów dworskiego życia, zawartych bezpośrednio w dziele De nugis curialium, nietrudno oprzeć się wrażeniu, że historia dworu Herli ma wydźwięk symboliczny i metaforyczny oraz jest bezpośrednim nawiązaniem do osobistych doświadczeń autora. $Z$ całą pewnością opowieść tę można odczytać jako nieco tylko zawoalowaną krytykę wątpliwej i złudnej kariery na monarszym dworze. Królewski klerk Walter Map niejednokrotnie dawał wyraz swemu niezadowoleniu z niekończącej się wędrówki-tułaczki jego i jemu podobnych w służbie Henryka II. W gorzkich słowach opisywał bezustanne podróże orszaku monarchy i zamieszanie związane z ciągłym przemieszczaniem się wielkiej rzeszy ludzi, wskazywał też na niestałość osobowego składu dworu. W słowach tych przebija się frustracja wynikająca z niespełnionych ambicji, której kulminacją jest fragment, gdzie Map przyrównuje dwór do piekła, zaś pobyt w nim do kary za grzechy $^{32}$. Tułacze życie króla Herli i jego świty stanowi w pewnej mierze odzwierciedlenie osobistych doświadczeń autora przekazu.

Podsumowując niniejsze rozważania, należy zwrócić uwagę na fakt, że za sprawą duchownych XII-wiecznych intelektualistów narodzony najpewniej jeszcze w pogańskiej starożytności motyw czarnych jeźdźców w średniowieczu nie tylko nie zaniknął, ale w wyjątkowym dla rozwoju kultury europejskiej XII stuleciu został znacząco rozbudowany, a przede wszystkim udokumentowany w utworach narracyjnych, tym samym uzyskując nową, trwałą żywotność. Fabuły z udziałem rzeczonego wątku, skonstruowane przez Orderica Vitalisa, anonimowego mnicha, autora kroniki z Peterborough, i wreszcie królewskiego klerka, Waltera Mapa, były za każdym razem odzwierciedleniem trosk i lęków, które zaprzątały wyobraźnię średniowiecznych autorów, ale też społeczności, do jakich należeli. Jak można było zaobserwować powyżej, wątek czarnych jeźdźców pojawiał się w różnych odsłonach i pełnił rozmaite funkcje. Orderic Vitalis wykorzystał go, solidnie rozbudowując, jako przyczynek do dyskusji o czyśćcu, podczas gdy jego anonimowy współbrat z opactwa w Peterborough sugestywnie zilustrował przy pomocy czarnych jeźdźców dostrzegany przez lokalną wspólnotę problem „złego opata”. Bardziej osobisty charakter miały refleksje Waltera Mapa, który historię jeźdźców króla Herli eksploatował w osobistej skardze na niedole dworskiego życia. Bez wątpienia, za sprawą trzech autorów i dzięki ich pisarskiemu talentowi, motyw czarnych jeźdźców na trwałe zadomowił się w europejskiej kulturze, również w kolejnych epokach, co znajduje potwierdzenie współcześnie, między innymi w twórczości Johna R.R. Tolkiena.

32 R. Bubczyk, Średniowieczny dwór angielski w oczach obcych. Przyktad Waltera Mapa, dworzanina Henryka II Plantageneta, [w:] Swoi i obcy w kulturześredniowiecza, red. M. B r zos tow ic z, M. Pr zy byl, J. Wrzesiński, Poznań-Ląd 2011, s. 122-133. 


\section{BIBLIOGRAFIA}

Źródła:

The Anglo-Saxon Chronicle, tłum. na j. ang. i oprac. D. Whitelock, D.C. Douglas, S.I. Tucker, London 1961.

The Ecclesiastical History of Orderic Vitalis, vol. 4, ks. VII i VIII, ed. M. Chibnall, Oxford 1983.

Tolkien J.R.R., The Lord of the Rings, London 1954-1955.

Walter Map, De nugis curialium. Courtiers' Trifles, oprac. i tłum. M.R. James, R. Mynors, Oxford 1983.

\section{Opracowania:}

A she L., The Written World: Past and Place in the Work of Orderic Vitalis by Amanda Jane Hingst, „The Journal of English and Germanic Philology”, 2010, vol. 109, No. 4, s. 527-530, https://doi. org/10.5406/jenglgermphil.109.4.0527.

Bartlett R., The Natural and the Supernatural in the Middle Ages, Cambridge 2006.

Bubczyk R., Średniowieczny dwór angielski w oczach obcych. Przyktad Waltera Mapa, dworzanina Henryka II Plantageneta, [w:] Swoi i obcy w kulturze średniowiecza, red. M. Brzostowicz, M. Przybył, J. Wrzesiński, Poznań-Ląd 2011.

Bubczyk R., W stużbie Kościota i króla. Waltera Mapa droga do kariery w czasach panowania angielskich Plantagenetów, [w:] Historia narrat. Studia mediewistyczne ofiarowane profesorowi Jackowi Banaszkiewiczowi, red. A. Pleszczyński [et al.], Lublin 2012.

Chapeaurouge de D., Symbole chrześcijańskie, tłum. G. Rawski, Kraków 2014.

Chibnall M., Introduction, [w:] The Ecclesiastical History of Orderic Vitalis, vol. 1, ks. I i II, ed. M. Chibnall, Oxford 1980.

Chojnowska-Haponik I., Tajemnice lasu Brocéliande. Legenda, rzeczywistość i wizja literacka, [w:] Flora i fauna w kulturze średniowiecza od XI do XV wieku, red. A. Karłowska-Kamzowa, Poznań 1997.

Clark C., The Peterborough Chronicle, 1070-1154, Oxford 1958.

Danielewicz Z, Niebo. Historia przysztości, Warszawa 2005.

European Transformations. The Long Twelfth Century, eds. T. Noble, J. van Engen, Notre Dame 2012. Flori J., Rycerze i rycerstwo w średniowieczu, tłum. E. Trojańska, Poznań 2003.

Forstner D., Świat symboliki chrześcijańskiej, ttum. W. Zakrzewska [et al.], Warszawa 1990.

Frugoni Ch., Books, Banks, Buttons and Other Inventions from the Middle Ages, New York 2003.

Gardiner E., Medieval Visions of Heaven and Hell. A Sourcebook, New York-London 1993.

Henryk z Sawtry, Czyściec Świętego Patryka, tłum. i oprac. J. Sokolski, Wrocław 2014.

Hingst A.J., The Written World. Past and Place in the Work of Orderic Vitalis, Notre Dame 2009.

Kobielus S., Bestiarium chrześcijańskie. Zwierzęta w symbolice i interpretacji. Starożytność i średniowiecze, Warszawa 2002.

Kobielus S., Florarium christianum. Symbolika roślin - chrześcijańska starożytność i średniowiecze, Kraków 2014.

Kusiak F., Rycerze średniowiecznej Europy tacińskiej, Warszawa 2002.

Lawrence C.H., Monastycyzm średniowieczny, tłum. J. Tyczyńska, Warszawa 2005.

Le Goff J., Narodziny czyśćca, tłum. K. Kocjan, Warszawa 1997.

Le Goff J., Niezwykli bohaterowie i cudowne budowle średniowiecza, tłum. K. Marczewska, Warszawa 2011. 
Messadié G., Diabet. Historia powszechna, tłum. K. Szeżyńska-Maćkowiak, Warszawa 1998.

Nola di A.M., Diabet, tłum. I. Kania, wyd. 2, Kraków 2000.

Orderic Vitalis. Life, Works and Interpretations, ed. Ch. Rozier, Woodbridge 2016.

Otter M., Inventiones: Fiction and Referentiality in Twelfth-Century English Historical Writing, Chapel Hill-London 1996.

Pastoureau M., Średniowieczna gra symboli, tłum. H. Igalson-Tygielska, Warszawa 2006.

Piwowarczyk D., Obyczaj rycerski w Polsce późnośredniowiecznej (XIV-XV wiek), Warszawa 1998.

Reeves C., Pleasures and Pastimes in Medieval England, Stroud 1995.

Rożek M., Diabet w kulturze polskiej. Szkice z dziejów motywu i postaci, Warszawa-Kraków 1993.

Rudwin M., Diabet w legendzie i literaturze, tłum. J. Illg, Kraków 1999.

Samsonowicz A., Łowy - praca, zabawa, obyczaj, [w:] Cztowiek i przyroda w średniowieczu i we wczesnym okresie nowożytnym, red. W. Iwańczak, K. Bracha, Warszawa 2000.

Schmitt J.-C., Duchy. Żywi i umarli w spoteczeństwie średniowiecznym, tłum. A.W. Labuda, GdańskWarszawa 2002.

Słupecki L., Wojownicy i wilkotaki, Warszawa 1994.

Turner A., Historia piekta, tłum. J. Jarniewicz, Gdańsk 2004.

Watkins C., History and the Supernatural in Medieval England, Cambridge 2007, https://doi. org/10.1017/CBO9780511496257.

Wei I.P., Intellectual Culture in Medieval Paris, Cambridge 2012, https://doi.org/10.1017/ CBO9780511842108.

White M., Tolkien. Biografia, tłum. K. Majchrzak, M. Majchrzak, Poznań 2004.

Varvaro A., Apparizioni fantastiche. Tradizioni folcloriche e letteratura nel Medioevo, Mulino 1994.

Zalewska-Lorkiewicz K., Książe ciemności. O średniowiecznych wyobrażeniach szatana, Warszawa 1996. 